\title{
Survey Based Study on Attitude of Final Year Degree Students towards Value Education in Chittoor Town.
}

\author{
Mrs. T. N. Rama, Sri. Y. Vasudhakar Reddy \\ Zoology PGT, A.P. Model School, Andhra Pradesh, India. \\ Principal, Sri Venkateswara College of Education, Chittoor, Andhra Pradesh, India.
}

\begin{abstract}
The main purpose of this study was to examine the attitude of final year degree students towards value education in Chittoor town. In this study, random sampling method was adopted. The participants of the study were 320 final year degree students of Chittoor town, Andhra Pradesh, India in 2013-2014 session. The tool used in the study for data collection was a 70 item questionnaire developed by the researchers by reviewing a number of books, news paper articles dealing with value education. The views expressed by different persons were collected in the form of statements and all the options thus obtained were pooled for coming to a conclusion. The intrinsic validity of the tool was established. The reliability of the tool was established using split half method which was found to be 0.91. This was correlated for full length by Spearman brown prophecy formula which was found to be 0.95. Data was analyzed using descriptive statistical methods ( mean, median, mode, standard deviation ), skewness, kurtosis and differential analysis using $t$-test. The findings of the study revealed that entire sample of students had a positive but significant difference in their attitude towards value education. Based on the findings, suggestions were made that same study may be extended to other towns, districts, first and second year degree students, MBA, MCA, diploma, engineering and medical colleges etc. Different other variables like socio-economic status, religion, caste etc. can be included.

Keywords: value education, final year degree, random sampling, intrinsic validity, split half method, spearman brown prophecy formula, descriptive statistical methods, differential analysis.
\end{abstract}

\section{Introduction}

India is a spiritual land with rich culture. Its philosophy is full of values. Its values are reflected in every aspect of its life and practice. Values are the essence of cultural and civilized society.

Indian society is marked by spiritualism, principles of honesty, obedience and non-violence. Morals are such human behaviours which are deemed to be right or good in a society. Values are described as the socially defined desires and goals that are internalized through the process of condition, learning and socialism. In order to make value education as a powerful tool, education shall be made more open, more reflective and more vocal with greater participation of teachers, students, parents and society in deciding all major aspects of education. Education is intrinsically and by definition value oriented.

\section{VALUES- DEFINITION}

Values reflect different philosophical positions. The concept of values are closely associated with the concept of man.

According to Oxford dictionary, values means worth.

According to Jules Henry in "Culture against Man" (1963), values are something that we consider good such as love, kindness, quietness, contentment, fun, honesty, decency, relaxations and simplicity. preference.

According to Carl Rogers in "Freedom to learn" (1969), valuing is tendency of a person to show

According to Brubacher, "to state one's aim of education is at once to state his educational values". education.

Educational values are those activities, which are good, useful, valuable from the point of view of

\section{TYPES OF VALUES}

Values are classified into two broad types according to Western philosophers. They are Absolute values and Pragmatic/Magnetic values. Values are classified into four types according to Indian philosophers. They are Dharma (Virtue), Artha (Wealth), Karma (Pleasure) and Moksha (Self-realization). In these four values, Dharma is a moral value. Karma is psychological value. Artha is economic value and Moksha is a spiritual value. 


\section{CLASSIFICATION OF VALUES}

Plato's classification: Truth, Beauty and Goodness.

Springer's classification: Theoretical values, Economic values, Aesthetic values, Social values, Political values and Religious values.

In general, values are classified as personal, social, normal, spiritual and behaviour values.

Gandhi's Classification: In order to create new special order, Gandhi introduced "Nai-talim" in the year 1937, which is popularly known as Basic Education.

- Truth

- Non-violence

- Freedom

- Democracy

- Sarva dharma samabhava

- Equality

- Self-realization

- Purity of ends and means

- $\quad$ Suddhi

Value system contains:

- A set of beliefs about the nature of men.

- Motivates that include us to choose the right and wrong.

- Beliefs about ideals that what are good or desolate worthy of pursuit for its own sake.

\section{VALUE EDUCATION}

Value education means calculating in the children, a sense humanism, a deep concern for the well being of others and the nation.

\section{ACADEMIC EDUCATION HELPS:}

- To develop 3R's -reading, writing and arithmetic.

- Try to manage simple things in daily life.

- Try to get a good job.

\section{VALUE EDUCATION HELPS:}

- Behavioral development.

- Importing fruitful education

- Helps to develop welfare of the self and others.

\section{OBJECTIVES OF VALUE EDUCATION}

- To train children to become responsible citizens in their personal, social lives.

- To create in children an awareness of the socio-economic conditions and to motivate them to improve the same.

The education reform document challenges of education (1985) enlists the following value orientation objectives:

- Physical, intellectual and aesthetic development of personality.

- Inculcation of a scientific temper and democratic, moral and spiritual values.

- Fostering a healthy attitude to dignity of labour and hand work.

- A commitment to principles of secularism and social justice.

- Promotion of international understanding.

- Development of self-confidence to innovate and face unfamiliar situations.

- Creation of awareness of physical, social, technological, economic and cultural development.

- A dedication to uphold the integrity and honor and foster the development of the country.

\section{NEED FOR VALUE ORIENTED EDUCATION}

- Moral development

- Cultural development

- Development of wider attitude.

- Development of democratic qualities 
- Sublimation of instants

- Resolving conflicts

- Co-operative living

- Basis of humanitarianism

- De Croatian of soul

- Maintaining harmony

\section{STATEMENT OF THE PROBLEM AND PURPOSE OF THE STUDY}

The problem selected by the researchers for the present study was entitled as "Survey based study on attitude of final year degree students towards value education in Chittoor town".

The purpose of the study was

- To identify the various values among the sample of final year degree students.

- To identify the various components and factors, which influence various types of values and their possession.

- To investigate the relationship between values and education in final year degree students.

- To investigate the significance of value-oriented education with variables like sex, group, management and locality of students.

\section{Methodology}

In this study, Random sampling method was adopted.

\section{Location and sample of the study.}

The research was conducted on a random sample of 320 final year degree students

of four degree colleges (two Government degree colleges and two Private degree colleges) of chittoor town, Andhra Pradesh, India.

Table 1: Distribution of the samples.

\begin{tabular}{|c|c|c|c|c|c|c|c|c|}
\hline \multirow{2}{*}{$\begin{array}{c}\text { Locality of } \\
\text { Students }\end{array}$} & \multirow{2}{*}{$\begin{array}{c}\text { Group of } \\
\text { the Students }\end{array}$} & \multicolumn{2}{|c|}{ Government management } & \multicolumn{2}{|c|}{ Private Management } & \multicolumn{2}{|c|}{ Total } & \multirow{2}{*}{$\begin{array}{c}\text { Grand } \\
\text { Total }\end{array}$} \\
\hline & & Male & Female & Male & Female & Male & Female & \\
\hline \multirow{2}{*}{ Urban } & Science & 35 & 35 & 15 & 15 & 50 & 50 & 100 \\
\hline & Arts & 35 & 35 & 15 & 15 & 50 & 50 & 100 \\
\hline \multirow{2}{*}{ Rural } & Science & 15 & 15 & 15 & 15 & 30 & 30 & 60 \\
\hline & Arts & 15 & 15 & 15 & 15 & 30 & 30 & 60 \\
\hline & & & & & & & & 320 \\
\hline
\end{tabular}

\section{Tool used for data collection}

The tool used for data collection was a 70 item questionnaire developed by the researchers by modifying the questionnaires of previous researchers who worked in the area of value education.

The questionnaire included student's personal information, 70 statements regarding value education posed to students to elicit information on the degree of agreement/disagreement.

Out of 70 items, statements with numbers 4,7,11,15,16,23,25,67,68 are negative statements while remaining are positive statements.

The Likert's method of summated ratings was used and the weightings on the five point scale were Strongly Agree $(\mathrm{SA})=5$, Agree $(\mathrm{A})=4$, Undecided $(\mathrm{U})=3$, Disagree $(\mathrm{D})=2$, Strongly Disagree $(\mathrm{SD})=1$ for positive statements and Strongly Agree $(S A)=1$, Agree $(A)=2$, Undecided $(U)=3$, Disagree $(D)=4$, Strongly Disagree $(\mathrm{SD})=5$ for negative statements. A student's score is the sum of all the scores for the 70 statements.

\section{Validity and Reliability of the tool}

The content, item, predictive and intrinsic validity of the tool was established and the intrinsic validity of the tool was fount to be 0.95-0.975. The reliability of the tool was established using split half method which was found to be 0.91 . This was correlated for full length by Spearman brown prophecy formula which was found to be 0.95 .

\section{Method of Data collection}

The researchers distributed the questionnaires to the students with the help of lecturers who supervised students on value education. The filled in questionnaires were retained on the spot.

\section{Data analysis}

Descriptive statistics (Mean, Median, Mode and standard deviation), skewness, kurtosis of the attitude scores of the entire sample and its sub-samples were calculated.

The null hypothesis for sub samples was tested by employing ' $t$ ' test at $5 \%$ level of significance. 


$$
t=\frac{\overline{x_{1}}-\overline{x_{2}}}{\sqrt{\frac{\sigma 1^{2}}{n 1}+\frac{\sigma 2^{2}}{n 2}}} N t_{\left(n_{1}+n_{2}-1\right)} \text { at } 5 \% \text { level of significance }
$$

III. Results

The results were presented in line with research statements and hypothesis.

Table 2: Means and Standard Deviations of different variables and subgroups of final year degree

\begin{tabular}{|c|c|c|c|c|c|c|}
\hline S.No & CI & Limits & MP & $\mathbf{F}$ & CF & CPF \\
\hline 1 & $210-229$ & $209.5-229.5$ & 219.5 & 24 & 24 & 7.50 \\
\hline 2 & $230-249$ & $229.5-249.5$ & 239.5 & 40 & 64 & 20.00 \\
\hline 3 & $250-269$ & $249.5-269.5$ & 259.5 & 59 & 123 & 38.00 \\
\hline 4 & $270-289$ & $269.5-289.5$ & 279.5 & 84 & 207 & 64.69 \\
\hline 5 & $290-309$ & $289.5-309.5$ & 299.5 & 64 & 271 & 84.69 \\
\hline 6 & $310-329$ & $309.5-329.5$ & 319.5 & 37 & 308 & 96.25 \\
\hline 7 & $330-349$ & $329.5-349.5$ & 339.5 & 12 & 320 & 100.00 \\
\hline
\end{tabular}

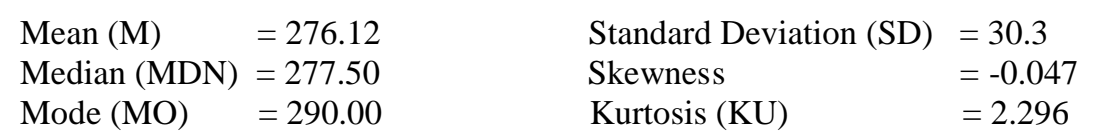

From the above table, it is clear that the mean and standard deviation score of final year degree students towards value oriented education for total sample of 320 id 276.12. Since Mean, Median and Mode are not the same, the curve may not be a normal. The kurtosis obtained is 2.296 is slightly greater than 0.263 . The peak of the curve will be plateau. In distribution, Mean is less than Median. So the skewness is negative and the peak is shifted towards left.

Figure 1 : Frequency Polygon showing the Frequency Attitudinal Scores of total Final Year Degree Students towards Value Oriented Education.

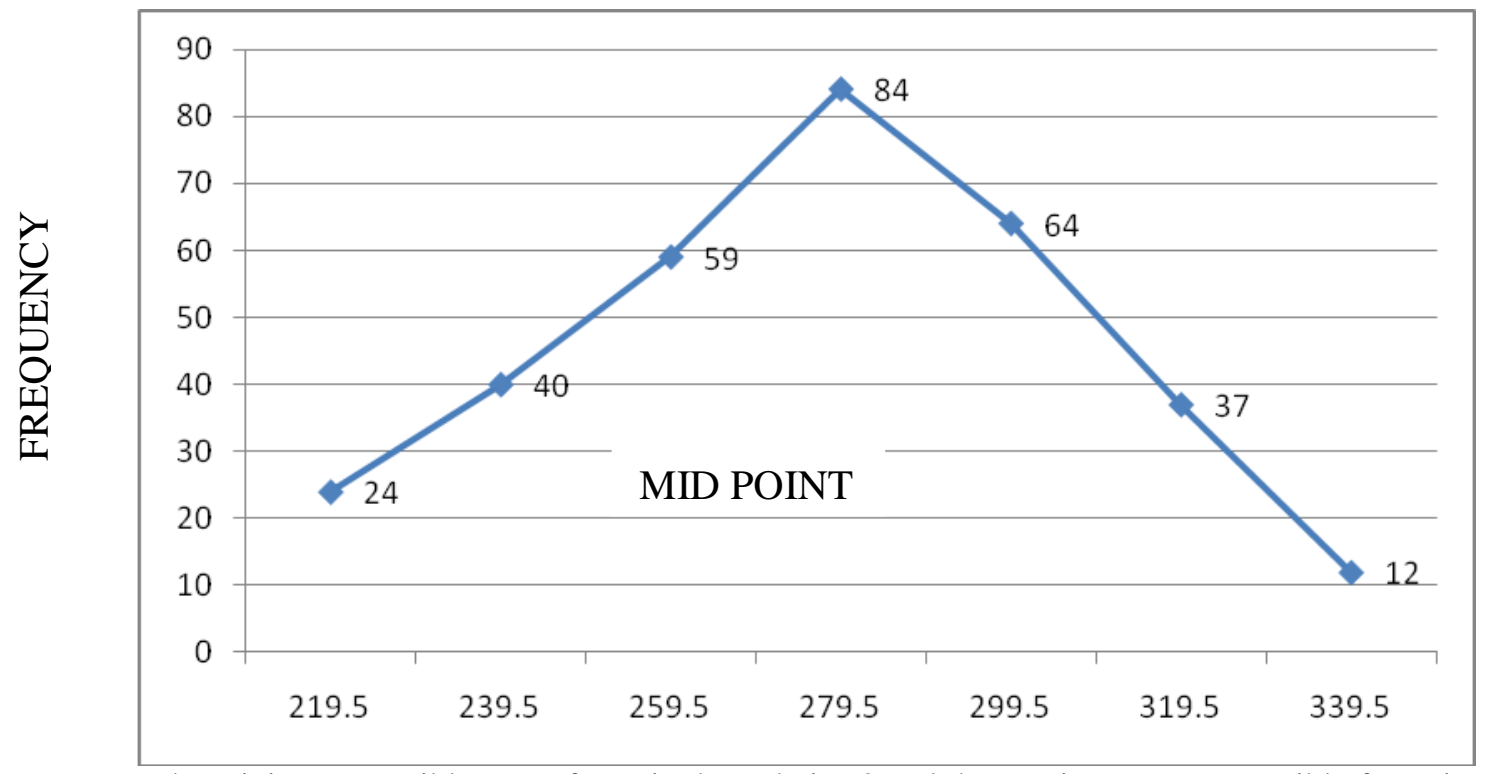

The minimum possible score for attitude scale is 70 and the maximum score possible for attitude scale is 350 . The mid value is $70+350 / 2=420 / 2=210$. It is the neutral point. Hence any score above 210 was considered as the positive attitude and below it was considered as the negative attitude. 
Table 3 : Means \& SDS of different variables \& sub groups of final year degree students towards Value Oriented Education.

\begin{tabular}{|l|l|l|l|l|}
\hline Variables & Sub Groups & N & Mean & SD \\
\hline \multirow{2}{*}{ Sex } & Male & 160 & 272.74 & 31.49 \\
\cline { 2 - 5 } & Female & 160 & 279.50 & 28.66 \\
\hline \multirow{2}{*}{ Group } & Arts & 160 & 273.93 & 30.94 \\
\cline { 2 - 6 } & Science & 160 & 278.18 & 29.53 \\
\hline \multirow{2}{*}{ Management } & Government & 200 & 273.13 & 29.15 \\
\cline { 2 - 6 } & Private & 120 & 281.10 & 31.50 \\
\hline \multirow{2}{*}{ Locality of Students } & Urban & 120 & 268.26 & 28.99 \\
\cline { 2 - 6 } & Rural & 289.23 & 27.79 \\
\hline
\end{tabular}

The calculated mean scores of subgroups ranged from 268.26 to 289.23 which were greater than 210 (neutral point). Hence all the final year degree students were having positive attitude towards value education.

The table value ' $t$ ' at $5 \%$ level of significance is 1.96 . The calculated ' $t$ ' value for all the subgroups were shown in the following table.

Table 4

\begin{tabular}{|c|c|c|c|c|}
\hline Sl. No & Variables & Sub Groups & t-Value & $\begin{array}{l}\text { Null Hypothesis } \\
\left(\mathbf{H}_{0}\right)\end{array}$ \\
\hline \multirow{2}{*}{1} & \multirow{2}{*}{ Sex } & Male & \multirow{2}{*}{2.009} & \multirow{2}{*}{ Rejected } \\
\hline & & Female & & \\
\hline \multirow{2}{*}{2} & \multirow{2}{*}{ Group } & Arts & \multirow{2}{*}{1.254} & \multirow{2}{*}{ Accepted } \\
\hline & & Science & & \\
\hline \multirow{2}{*}{3} & \multirow{2}{*}{ Management } & Government & \multirow{2}{*}{2.253} & \multirow{2}{*}{ Rejected } \\
\hline & & Private & & \\
\hline \multirow{2}{*}{4} & \multirow{2}{*}{ Locality of Students } & Urban & \multirow{2}{*}{6.429} & \multirow{2}{*}{ Rejected } \\
\hline & & Rural & & \\
\hline
\end{tabular}
education.

A conclusion was made that subgroups had a significant difference in their attitudes towards value

\section{Discussion}

From this study and the findings, it was fount that total sample of final year degree students were having positive attitude towards value education but a significant difference was found in the attitudes of subgroups.

\section{EDUCATIONAL IMPLICATIONS}

- Work experience in value oriented education help in perfecting skills, utilizing materials, tools and process of works.

- Value oriented education based teacher training program made nation builders in the form of teachers.

- Value oriented education at university stage include moral values and human values in students to make them better and more useful members of society.

- Value oriented education with a course in comparative religion promote social harmony, a liberal attitude and less fanatical approach to religion.

- Value oriented education will only eliminate obscurantism, religious phantasm, violence, superstitions and fatalism.

- Value oriented education strengthen accelerating the process of modernization and development of scientific temper and out look.

- Inculcating examples of national leaders in value oriented education, values can be included with in human case and natural setting.

- With the degree of realism in value oriented education, pupils are encouraged to live in the harmony with nature of arts, music and build good nation.

- The moral and value oriented education with the inclusion of common ethical teaching of all great religious highlights the nation utility.

- Only value based education system cultivate the basic values of humanism, democracy, socialism and secularism.

- Only value oriented education inculcate for motherland and proper praise in cultural heritage and achievements. 
- By inculcation of physical education, health, strength, ability and beauty can be laid.

- Stories, illustrations and events mainly from Indian nation and its literature from various religions that included in value oriented education leads to national integration.

- Sports centered value oriented education develops energetic action and decision and action sportsman ship and leadership qualities.

\section{Suggestions}

The same study may be extended to other towns, districts, first and second year degree students, MBA, MCA, B.Ed, M.Ed, diploma, engineering and medical colleges etc. Different other variables like socioeconomic status, religion, caste etc. can be included.

\section{References}

[1]. Allport, G.W., 1929. The composition of Political Attitudes American Journal of Society, 35, pp 220-238.

[2]. Anderson, L.R. and Fish Being, M., 1965. A composition of summation and cognitive theories, pp 443/473.

[3]. Aurobindo, 1950. The ideals of Human Unity, Pondicherry, Sriaravind Asha.

[4]. Babu Sreedhar, P., 2000. An analytical study of high school students attitudes towards value oriented education in Anantapur district, M.Ed. Dissertation, Dept. of Edcuation, S.V.University, Tirupati.

[5]. Baldown, J.M., 1905. Dictionary of Philosophy and Psychology, Mc Milon, Newyork.

[6]. Bantas T.J. Social attitudes and response styles, Educational psychology measurement, 21, pp. 543-553.

[7]. Best John, W., 1963. Research in Education, Prentice hall of India (pvt.) Ltd., New Delhi.

[8]. Bhagavati Dayal, 1995. The development of Indian Edcuation, Orient Longmans Co.Ltd., Madras, P.I.

[9]. Black man, H., 1975. The curriculum in Moral Edcuation in Taylore, M.Ed. Program and problems in moral education, slough national foundation of educational research.

[10]. Bogardus, E.W., 1931. Fundamental social psychology centuray, New york, pp.62.

[11]. Buch, M.B., 1992. Fourth survey of Research in Education, Society of Educational Research and Development , Baroda.

[12]. Cadwell, C.W., and Acutis, S., 1923. Then and now in education, 1845,1923, World book company, London, pp.37.

[13]. Cole, W.G., 1987. The Restless Quest of Modern Man (in relevance of value education today) Value education; Today's challenge, Nirmala Convent, Mysore, pp.3.

[14]. Dayakar Reddy, V., Value oriented education, Discover publication house - 2 published - 2006., New Delhi - 110002.

[15]. Dagar, B.S. and Dhull, I.A., 1998. Case for value oriented education, university news, 35(29), july $21^{\text {st }}$.

[16]. Dayakar Reddy, V. and Shridhar Babu, 2002. Experiments in education, a study of the attitude of intermediate students towards value oriented education.

[17]. Dayakar Reddy, V. and A. Lakshmidevi "An analytical study of value oriented education towards high school children in Kadapa District”.

[18]. Deshmukh C. Pranava, 2003. Abstraction values oriented education.

[19]. Dileep Kumar, 2004. A Study of attitude of the graduate students towards value oriented education in S.V. University.

[20]. Dayakar Reddy and Digumurthy Bhaskar Rao (2006) Value oriented education (Discovery publishing House New Delhi 110002).

[21]. Edward Kil Patrick, F.P., 1948a,1948b. A Technique for the construction of attitude scales, J. Applied Psychology, 33,pp. 374/384.

[22]. Gail M. Inlaw, 1972. Values in transition, a hand book, John Willey and sons, Inc., New York.

[23]. Gandhi, M.K. 1927-76. An Autobiography., Ahmedabad, Navjivan Publishing Company, Faridabad, Haryana., pp. 33-90.

[24]. Gupta, N.L. 1986. Value Eduation, Theory and Practice, Krishna Brothers, Ajmeer.

[25]. Gurugaj, Kaarajagi, 2oo3. Role of Teachers and Parents in impacting Values.

[26]. Indira, R., 2003. Women's Employment and Value Education.

[27]. Prof: C.Maheswari - 2003. NCTE, Chairman, Value oriented education in teacher education.

[28]. Morill, Richard, L., 1980. Teaching values in college, San Francisco, Washington, Jossey Bass Publishers.

[29]. Pinion, F.B., 1964. Educational values in an age of technology, the Mc Millan and co, New York, 1964.

[30]. Ramprasad, K. 2003. A study of attitudes of post graduate students towards value education in S.V.University, M.Ed., Dissertation , Dept. of Education, S.V.University, Tirupati.

[31]. Saraf, S.N., 1995. Education in Human Valued Programme Implementation, New Delhi.

[32]. Shetty, A., Khirwadkar, A. and Tomor, A. 1997, Value education need for the present generation, University News, 35(41), October, 13.

[33]. Shirmalil, K.L., 1971. A search for Values in Indian Education, Vikas Publications, Delhi.

[34]. Sri Sri Sitaramadas Omkaraath Samskrith sikshal Samsad, 203. National seminar philosophy of Indian nationalism and value oriented education.

[35]. Vivekananda Swamy, 1965-1998. Complete work of Swamy Vivekananda, Calcutta, Adavaik Ashram.

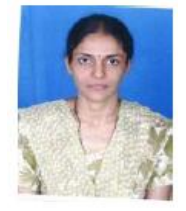

Mrs. T.N.Rama M.Sc.,M.Phil., M.Ed. is currently working as Zoology PGT in A.P. Model School, Government of Andhra Pradesh, India. She pursued B.Ed. and M.Ed. in Sri Venkateswara College of Education, Chittoor, Andhra Pradesh, India. Her Research area is related to Value Education.

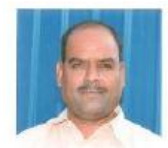

Sri.Y.Vasudhakar Reddy M.A., M.Phil., M.Ed., Ph.D. is currently working as Principal in Sri Venkateswara College of Education, Chittoor, Andhra Pradesh, India. His Research area is related to Value Education. 